\title{
2
}

\section{Archaeological Excavations on Itbayat and Siayan Islands}

\author{
Peter Bellwood, Eusebio Dizon and Armand Mijares
}

This chapter describes the layout of excavations and the stratigraphy revealed in Torongan and Reranum caves on Itbayat Island, occupied between 4000 and 3000 years ago, together with the major hill-top habitation site of Anaro, with its circle-stamped pottery and prolific evidence for working of Taiwan nephrite and slate between 3000 and 2000 years ago. Also discussed are the excavations at Mitangeb on Siayan Island, which appears to have served as a satellite settlement from Itbayat about 2000 years ago.

Itbayat Island has a land area of 92.80 square $\mathrm{km}$ and is the largest island in Batanes. It is basically a raised coral formation that encloses a number of highly weathered volcanic outcrops, especially Santa Rosa in the north (Karovooban in Itbayaten) and Riposed in the east, rising to 277 and $229 \mathrm{~m}$ above sea level respectively (Fig. 2.1). Itbayat has mainly undulating terrain, with gorges where stream beds have cut into the raised coral. The fringes of the island are almost everywhere steep coral cliffs that sometimes rise sheer to 100 metres above sea level (Fig. 2.2), but in a few places there are gorges that allow access down to rocky shelves close to sea level from which boats can be launched. There are no beaches, no sloping coastal terrain that enters the sea, and access to and from the sea can most generously be described as difficult for much of the year, involving leaping on and off heaving boats from and on to slippery quays cut into coral. Needless to say, all boats must be pulled ashore after use, and cannot be moored in the sea. Nevertheless, modern Itbayatens still go fishing and spear-diving just like their forefathers, and many archaeological sites contain large amounts of marine shell, but with the problem that some has been weathered out of the raised coral reef geology and is thus of fossil origin. There are grave dangers here if one wishes to date shell artefacts by direct dates on the shell. No such shell artefact samples have been dated in this research project, although C14 dates have been measured on marine shells in situations where they can be assumed to be food discard, where they are fresh and not rolled or weathered, and without adhering limestone matrix from the uplifted coral reefs.

Itbayat today is mainly under swidden agriculture and pasture, with secondary forest in nonfarmed areas and some evergreen native forest in protected gorges. The longest river is the Torongan, that flows underground to the sea below Torongan Cave. Most stream beds on the island are dry nowadays for much of the year under natural circumstances, but they might have held more water under naturally-forested conditions in the past. Some contain pockets of 
permanent water, but damming to pond back water for humans and buffaloes has occurred very frequently in recent years and the presence of a dam is not always obvious without careful enquiry (see the final Appendix in this volume). Most soils are acidic clays and clay loams that support tuber crops, vegetables and fruit trees, but only very small hillside plots of dry rice are grown, and only during the monsoon season. There is no irrigated rice, neither on Itbayat nor throughout the Batanes Islands, perhaps because there are no alluvial valley bottoms that would favour irrigation and no reliable supplies of irrigation water. Terracing to grow rice has never been adopted, despite its importance in Mountain Province in nearby Luzon.

Siayan Island lies $8 \mathrm{~km}$ NNE of Itbayat, across a rough and exposed sea passage, and is just over one $1 \mathrm{~km}$ long. It is dominated by a volcanic pinnacle called Domnayjang (Fig. 2.3), the name apparently referring to the presence of an ijang fortification (Gaza and Yamada 1999:28), although no member of our team was willing to scale this relatively sheer and intimidating rock to look for it. The Mitangeb site that lies below was quite sufficient to keep us busy.

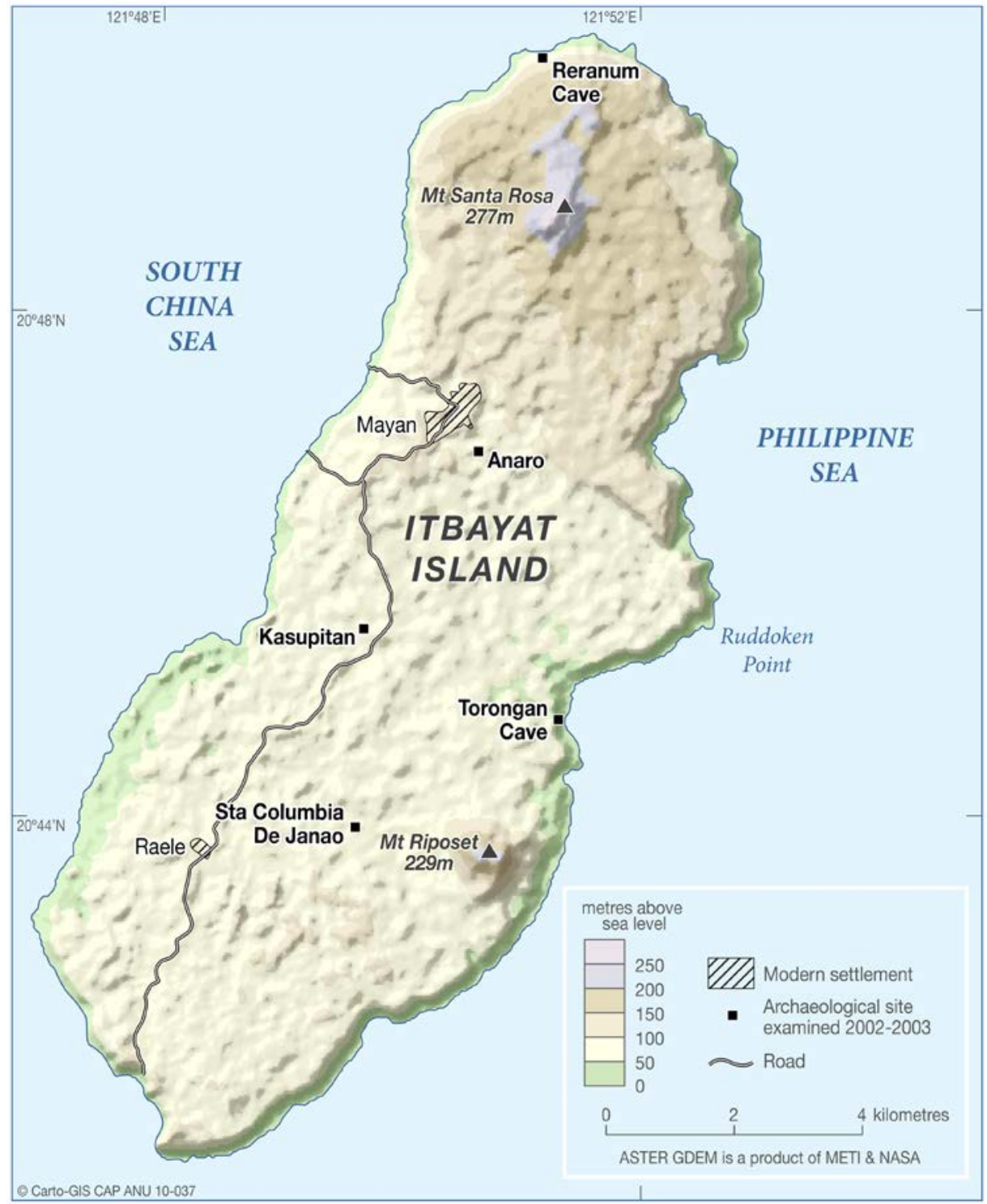

Figure 2.1. The island of Itbayat.

Source: Map preparation by ANU College of Asia and the Pacific, CartoGIS. 


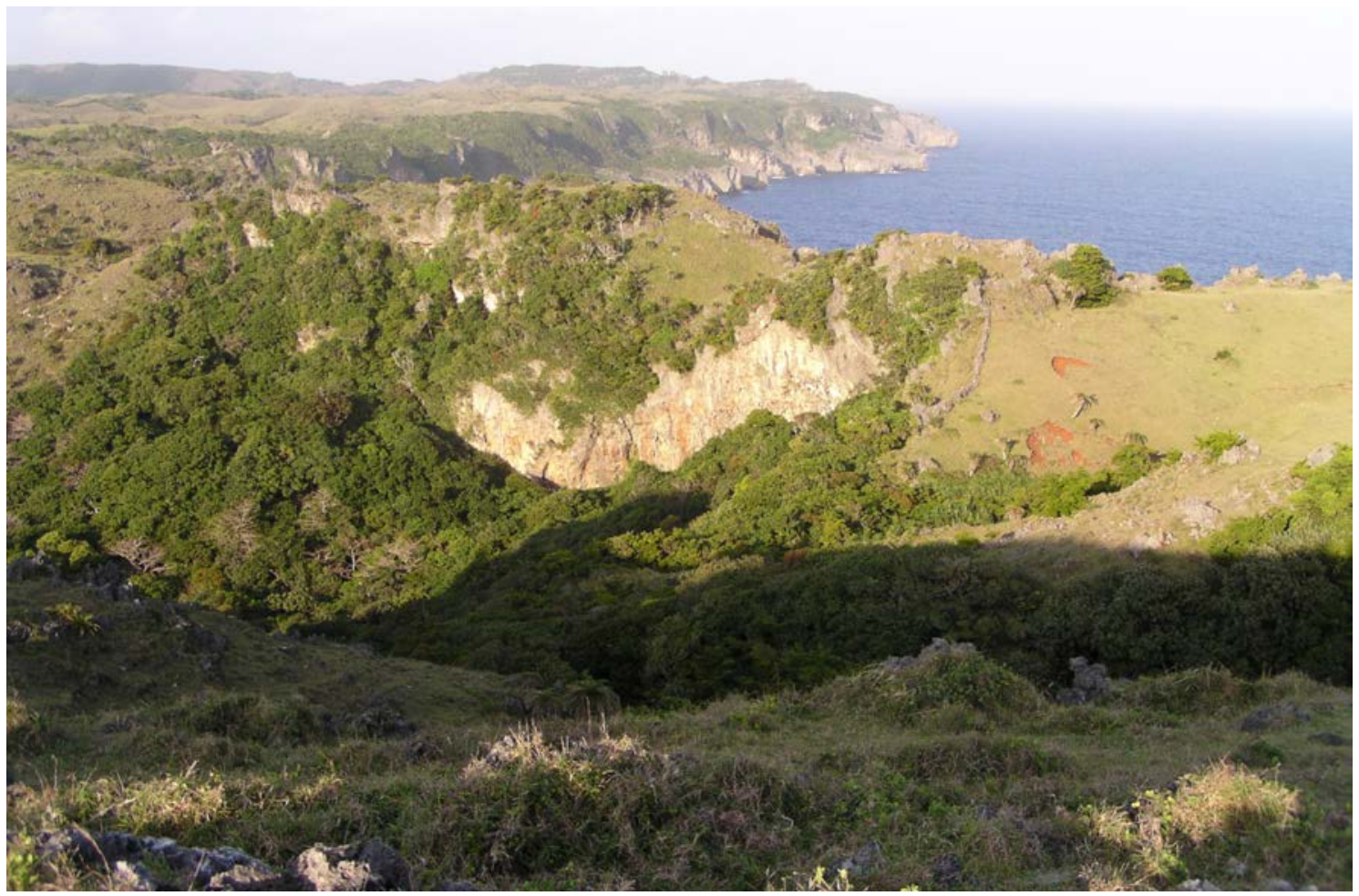

Figure 2.2. The eastern coastline of Itbayat, with the inland mouth of Torongan Cave in the centre (at base of cliff, hidden behind the trees).

Source: Peter Bellwood.

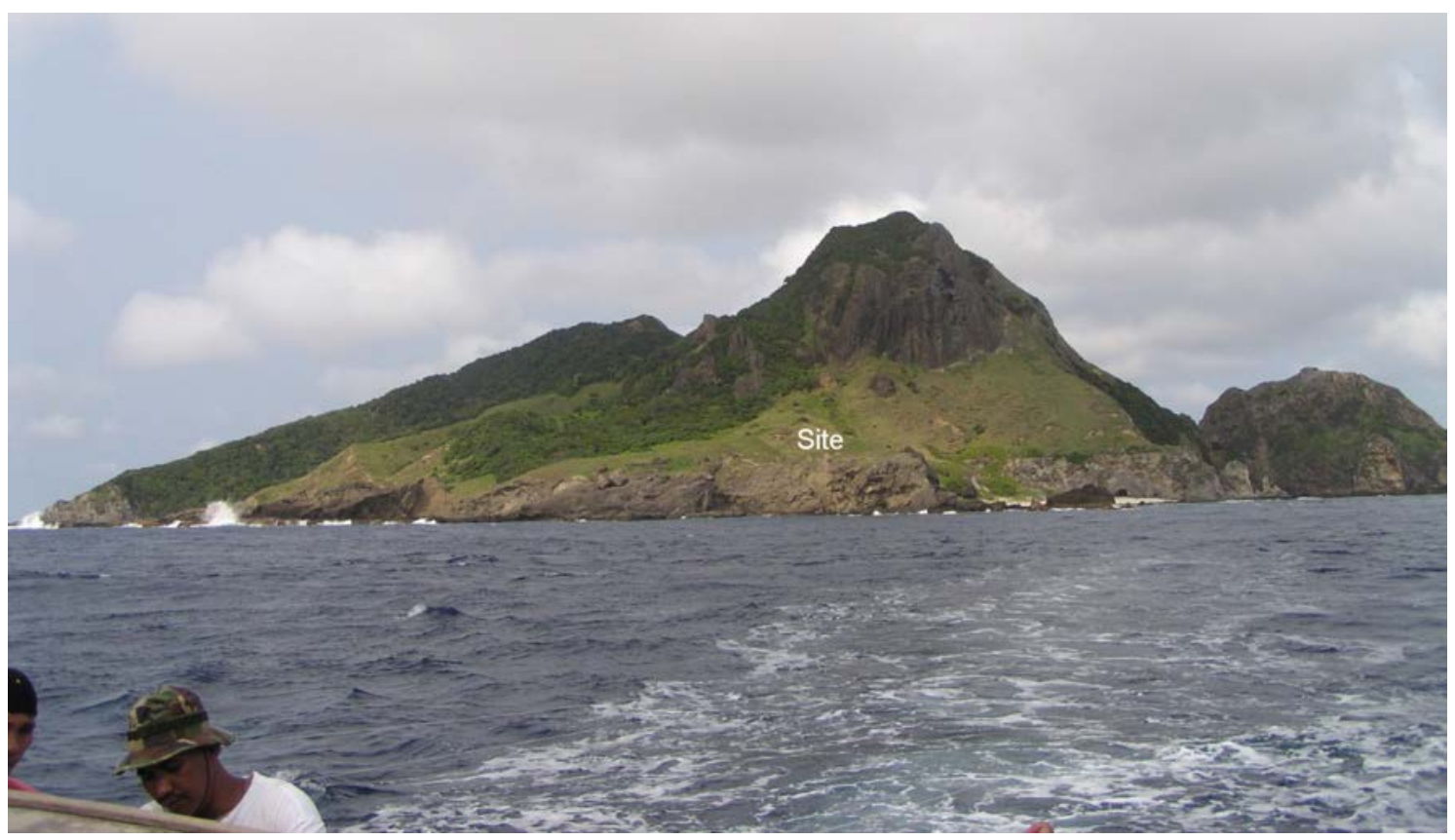

Figure 2.3. Siayan Island from the south, with the volcanic pinnacle of Domnayjang. Mitangeb is located just below the place marked "site".

Source: Peter Bellwood. 


\section{Torongan Cave}

The oldest archaeological assemblage known so far in Batanes comes from Torongan Cave on the east coast of Itbayat. Given the verticality and height of the Itbayat cliffs and the difficulties of landing boats, it is quite possible that Torongan, which opens at sea level, would have provided a landing place for early settlers, who could have beached their canoes in the lower cave (Fig. 2.4) and then climbed up through the interior to emerge eventually on the top of the island. The lowest portion of Torongan is so close to sea level that shallow water might have penetrated into it during any putative period of mid-Holocene higher sea level (not actually attested for Itbayat, but likely until about 4000 years ago from a regional perspective - see Sathiamurthy and Voris 2006: Fig. 26). The recent geological history of Itbayat has also been one of tectonic uplift, and indeed the lower part of the cave wall next to the sea entrance has a marked overhang, perhaps due to wave action. If relative sea level has dropped since $2000 \mathrm{BC}$, then the early inhabitants of Torongan Cave could have brought in their boats during summer periods of quiet sea. The sea does not penetrate the cave today.

The cave system is a $30 \mathrm{~m}$ high tunnel about $150 \mathrm{~m}$ long, with both seaward and inland entrances (Fig. 2.5). At one time it must have been occupied by the Torongan River, which now flows underground just before it reaches the cave. The inland entrance lies behind a steep pile of roof fall that rises high above the lowest part of the cave and hides the actual entrance from external view. This has to be climbed from outside and then descended in order to get into the relatively small archaeological region of the cave, which can be seen shaded in Fig. 2.5. This archaeological deposit is located about $13 \mathrm{~m}$ above the base of the cave, near the top of a high cone of fallen rock and soil piled against the southwestern wall of the inland mouth (Figs 2.6, 2.7).

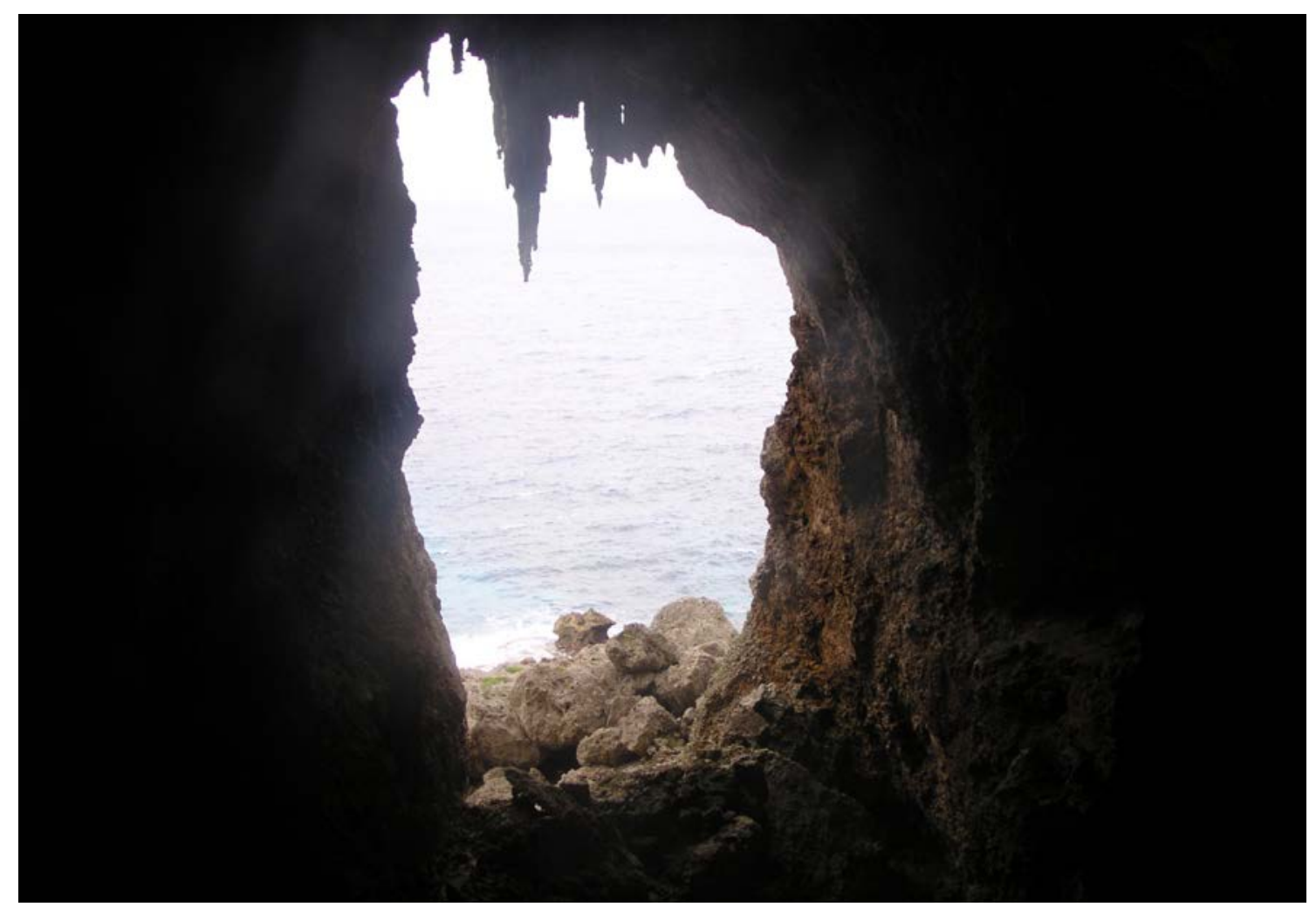

Figure 2.4. The Torongan Cave landing, photographed from inside the cave.

Source: Peter Bellwood. 


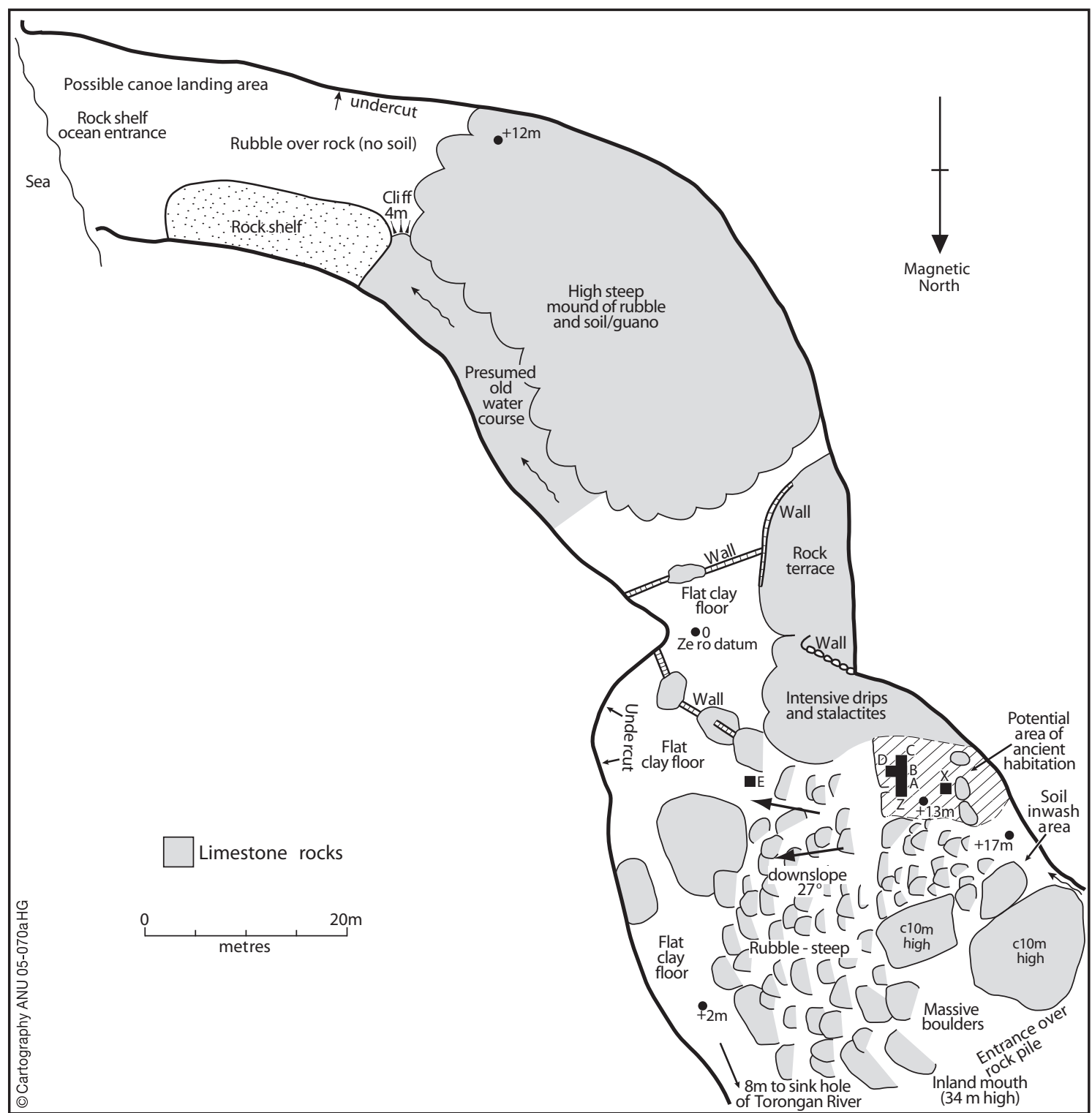

Figure 2.5. Plan of Torongan Cave, with the ocean exit at top left and the excavated area and inland mouth at bottom right. Heights in metres are above an arbitrary zero datum located in the middle of the cave.

Source: Map preparation by ANU College of Asia and the Pacific, CartoGIS.

Excavations were undertaken in 1X1 metre squares near the top of this cone in 2004 (squares A and B) and 2005 (squares C, D, X and Z). All materials in Torongan were dry-sieved through 3 and $5 \mathrm{~mm}$ meshes - no water was available to allow wet sieving. In squares $A$ to $D$, an in-washed layer of topsoil was found at about $40-65 \mathrm{~cm}$ depth, presumably released into the cave down the side of the inland mouth by forest clearance and occupational activity on the land surface above. Surface traces of a former open site were noted on top of the cave in 2005, alas eroded away down to the culturally sterile clay subsoil leaving just a few remnant potsherds. Above the topsoil in squares A to D the deposit became lighter, indicating continuing inflow of subsoil after the original topsoil had been washed down, but sherds became increasingly fewer towards the surface (Table 2.1). Because squares $\mathrm{X}$ and $\mathrm{Z}$ had been disturbed by downwards movement of sediment 
into deep voids in the scree slope, numbers of sherds by depth are not presented for these squares. Square E, dug in 2005 in the flat clay floor at the base of the cave, was archaeologically sterile and scoured by occasional flooding through the cave.

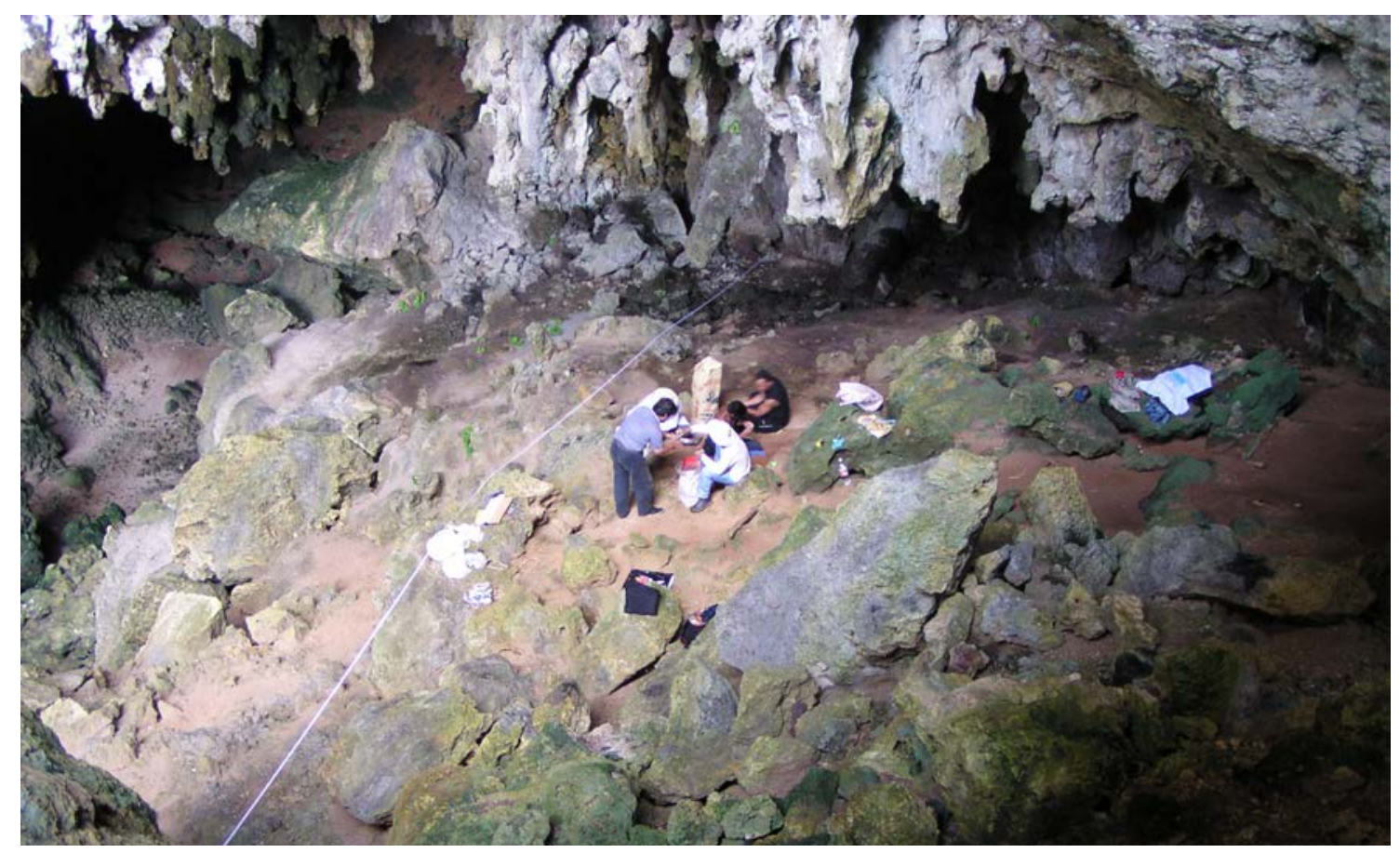

Figure 2.6. The 2004 excavation in the rock-filled interior of Torongan Cave, photographed from the high inland mouth of the cave. The lower cave floor is down at the left, with the remains of a dry stone wall visible at the rear.

Source: Peter Bellwood.

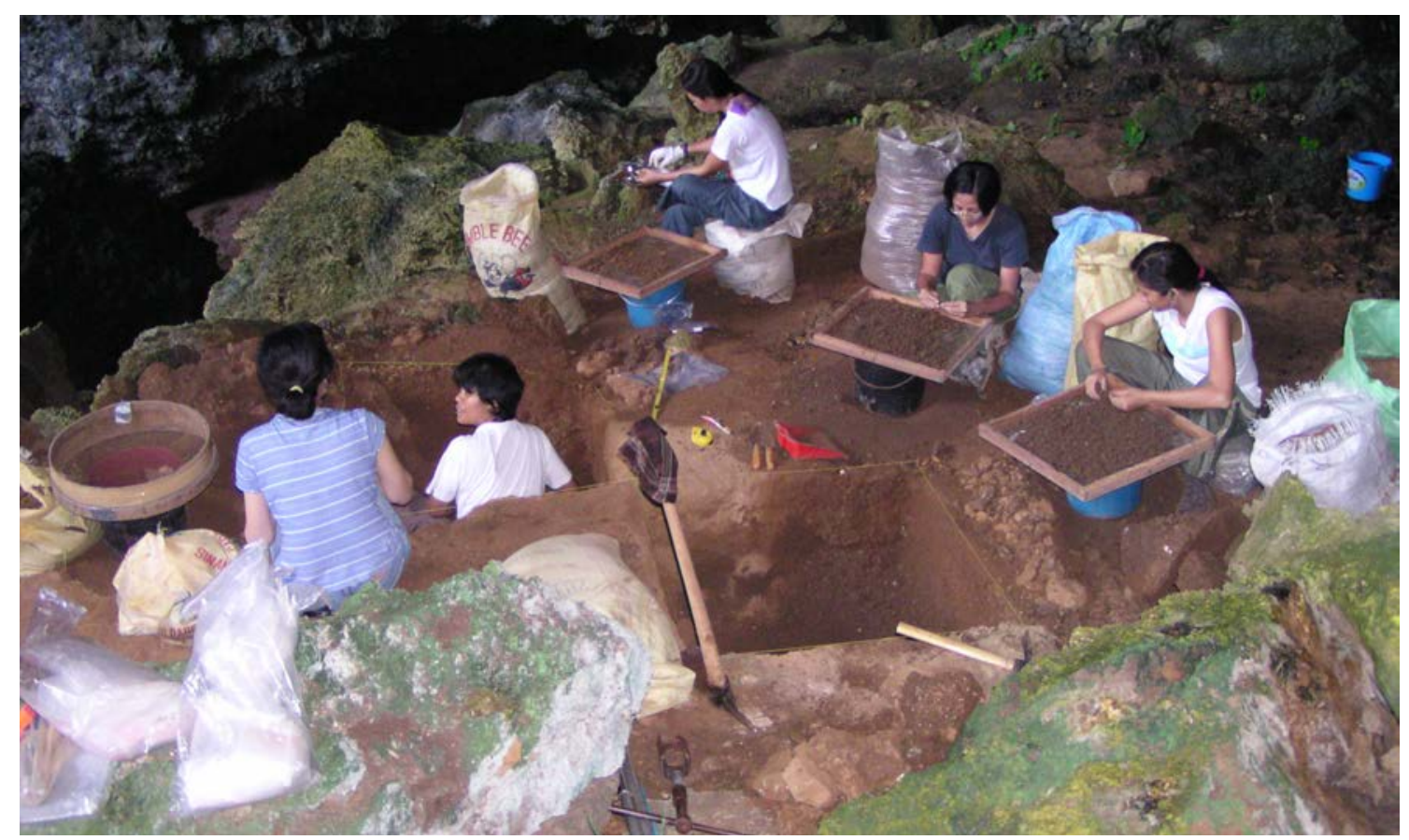

Figure 2.7. Excavation and sieving in Torongan Cave in 2005, squares C and D.

Source: Peter Bellwood. 
When we first visited Torongan we thought that all of the cultural material might have been washed in from above. However, the cave itself would also have been habitable as long as fresh water was available in the Torongan river bed outside or in the sink holes below the entrance. People could have slept on bamboo flooring laid over the rough and rocky floor of the cave, particularly over the excavated area, which was positioned away from overhanging and threatening stalactites. The cave has good light, and the ijang-like dry stone walls that occur further into the cave from the archaeological site (visible in Fig. 2.5) suggest that groups did live there occasionally in the recent past, perhaps hiding from enemies. For instance, a stone wall quite near the excavated area and marked on Fig. 2.5 (also visible behind and slightly to the left of the excavators in Fig. 2.6) seems to have been constructed to hide the surface of a rock terrace from prying eyes looking in from the northern mouth. However, very little midden material was found in the Torongan Cave excavations, despite good conditions for shell and bone preservation.

Table 2.1. The distribution of pottery (body sherds only) in Torongan Cave, 2004-5 excavations, squares A to D. Note the very high density in the in-washed topsoil layer (shaded). Counts for red-slipped sherds are minima, since red slip can be removed by weathering or masked by surface concretions on the sherds.

\begin{tabular}{|l|l|l|l|l|}
\hline Torongan A-D & Body sherd weight gm. & Body sherd number & Red slipped sherds (positively identified) & Circle stamped \\
\hline $0-5$ & 444 & 129 & 6 & 1 \\
\hline $5-10$ & 802 & 184 & 15 & \\
\hline $10-15$ & 553 & 130 & 13 & \\
\hline $15-20$ & 890 & 151 & 11 & \\
\hline $20-25$ & 524 & 178 & 13 & 1 \\
\hline $25-30$ & 616 & 193 & 21 & \\
\hline $30-35$ & 626 & 204 & 21 & \\
\hline $35-40$ & 934 & 281 & 19 & \\
\hline $40-45$ & 1723 & 361 & 50 & 1 \\
\hline $45-50$ & 1759 & 413 & 50 & \\
\hline $50-55$ & 1342 & 362 & 33 & \\
\hline $55-60$ & 744 & 173 & 11 & \\
\hline $60-65$ & 442 & 165 & 7 & \\
\hline $65-70$ & 142 & 58 & 4 & 3 \\
\hline $70-75$ & 148 & 37 & 5 & \\
\hline $75-80$ & 5 & 3 & 279 & \\
\hline Totals & 11694 & 3022 & & \\
\hline
\end{tabular}

The calibrated C14 dates from Torongan Cave point to a chronology for the in-washed topsoil layer between 2500/2000 and 1350 BC (Table 5.1 and chapter 5), although there are younger dates from higher in the profile suggesting that the site was visited over a long period, indeed into the Ming dynasty according to a coin of the emperor Wan Li (AD 1583-1620) found just below the surface. Torongan also has three circle-stamped sherds with white lime or clay infilling occurring relatively late in the sequence (Table 2.1), similar to the sherds with stamped circles dating between 1200 and 500 BC from Sunget, Anaro and Savidug (chapter 6). 


\section{Soil Micromorphology of Torongan Cave Sections (by Armand Mijares)}

Two oriented sediment samples collected in Kubiena tin boxes driven into the Torongan Cave section were impregnated, thin-sectioned, and studied under the microscope in the Archaeological Studies Program, University of the Philippines. The upper stratum $(0-40 \mathrm{~cm}$ depth) is a fine crumbly light to dark brown sediment. The lower stratum (40-65 cm depth) of apparently inwashed topsoil is a fine dark brown to black sediment. Descriptions are based on Bullock et al. (1985) and Stoops (1998).

The upper stratum has two sub-sections differentiated by microstructure. The upper has a moderately developed angular blocky structure with channels and intra-pedal cracks. The lower has a moderately developed crumb microstructure with packing voids and poroids. The difference between the two sub-sections is probably due to the lower sub-section being subjected to more bioturbation due to faunal activity (French 2003). This sub-section has an estimated 5-10 per cent porosity.

The ground mass of the upper stratum is poorly to moderately sorted with a coarse to fine ratio of 20/80 and a texture of silty clay. The ground mass has a stipple-speckle fabric with high birefringence. The colour in plane-polarized light (PPL) is brownish yellow, and yellowish brown in cross-polarized light (XPL).

Rounded andesite fragments $120-1500 \mu \mathrm{m}$ in size were observed. There were large fragments of limestone $(750 \mu \mathrm{m}-4 \mathrm{~mm})$ and calcite nodules $(300-700 \mu \mathrm{m})$. A few bone $(500 \mu \mathrm{m})$ and shell (500-1700 $\mu \mathrm{m})$ fragments were also observed. Other minerals observed were plagioclase $(100-$ $600 \mu \mathrm{m})$, amphibole $(120-500 \mu \mathrm{m})$, pyroxene $(250-250 \mu \mathrm{m})$, biotite $(250 \mu \mathrm{m})$ and quartz $(170$ $500 \mu \mathrm{m})$. A fragment of earthenware pottery $(12 \mathrm{~mm})$ was also recorded. Charcoal was the only organic material found, of rounded fragments $85-750 \mu \mathrm{m}$ in size.

The lower stratum has a weakly developed sub-angular blocky structure. Porosity is estimated at $10 \%$ with compound packing and intra-pedal cracks. The ground mass is yellowish brown in PPL and reddish yellow in XPL. It is poorly sorted, with a silty clay loam texture. The coarse to fine ratio is 15:85. The fabric has high birefringence with stipple-speckles. It also contains shell fragments $700 \mu \mathrm{m}-8 \mathrm{~mm}$ in size and bone fragments $7 \mathrm{~mm}$ in size. There are many limestone/ calcite fragments $(85 \mu \mathrm{m}-5 \mathrm{~mm})$ that are angular in shape. Other minerals observed were plagioclase $(85-700 \mu \mathrm{m})$, quartz $(50-200 \mu \mathrm{m})$, amphibole $(50-400 \mu \mathrm{m})$, biotite $(100-250 \mu \mathrm{m})$ and pyroxene $(250 \mu \mathrm{m})$. There were rounded to sub-rounded charcoal fragments $(100-850 \mu \mathrm{m})$, estimated at $2 \%$ by volume of the section.

Some grains or fragments have silty clay coatings. There were a lot of orange to red dirty clay peds $50-850 \mu \mathrm{m}$ in size. Large yellowish to red coloured peds with plagioclase and amphibole inclusions were also identified. These peds are from $1500 \mu \mathrm{m}$ to $3 \mathrm{~mm}$ in size and are rounded to sub-rounded.

In conclusion, the thin sections from Torongan Cave show some bioturbation, especially in the upper stratum. This can be seen in the crumbly structure and the poroids made by faunal activity. Both strata showed some degree of movement in their rounded rock fragments and charcoal inclusions. Red-orange peds and dirty clay were also observed, probably derived from outside the cave. These features are characteristic of developed soils that could have been washed into the cave from above. 


\section{Reranum rockshelter}

Reranum rockshelter (Fig. 2.8) is located about half-way down the terraced raised coral northern perimeter of Itbayat Island, looking out towards Siayan Island (Fig. 2.9). This is an area where landing would have been very difficult, except in very calm seas. However, the presence of a reliable fresh water spring in the cliff below the site means that the cave would have been habitable. Boats heading for Siayan Island from the two modern landings of Mayan township, located at Chinapoliran and Paganaman, sometimes stop and take on fresh water here, since getting ashore on to the narrow limestone shelf is possible in very calm seas. Normally, however, we might expect Reranum shelter to have been accessed from the landward side, since the climb down from the island top is quite easy. The land above the cave where we camped in 2006 is gently sloping, and lightly strewn with recent potsherds.

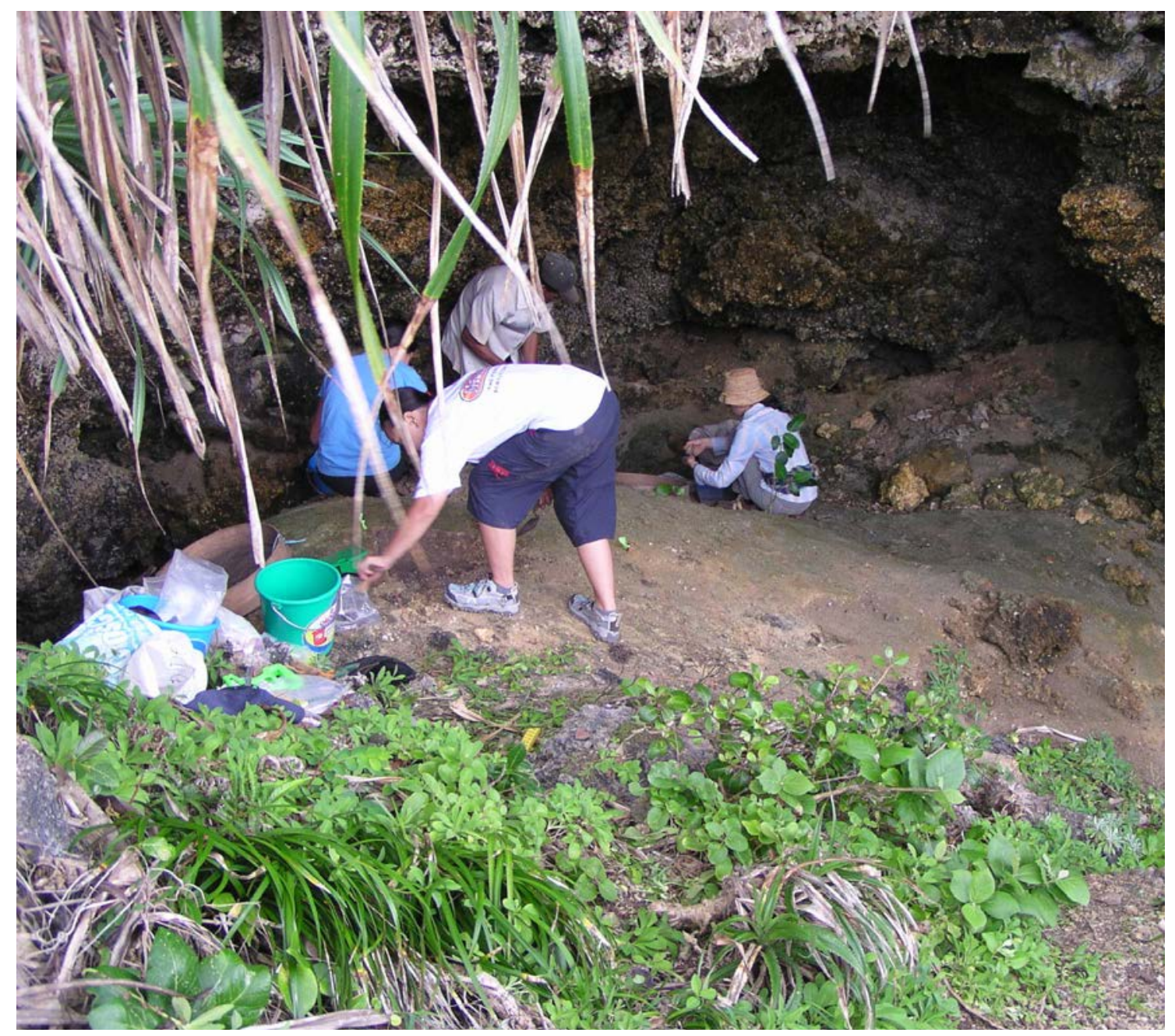

Figure 2.8. Reranum shelter before excavation. The right hand area had most of its soil removed before our visit.

Source: Peter Bellwood. 


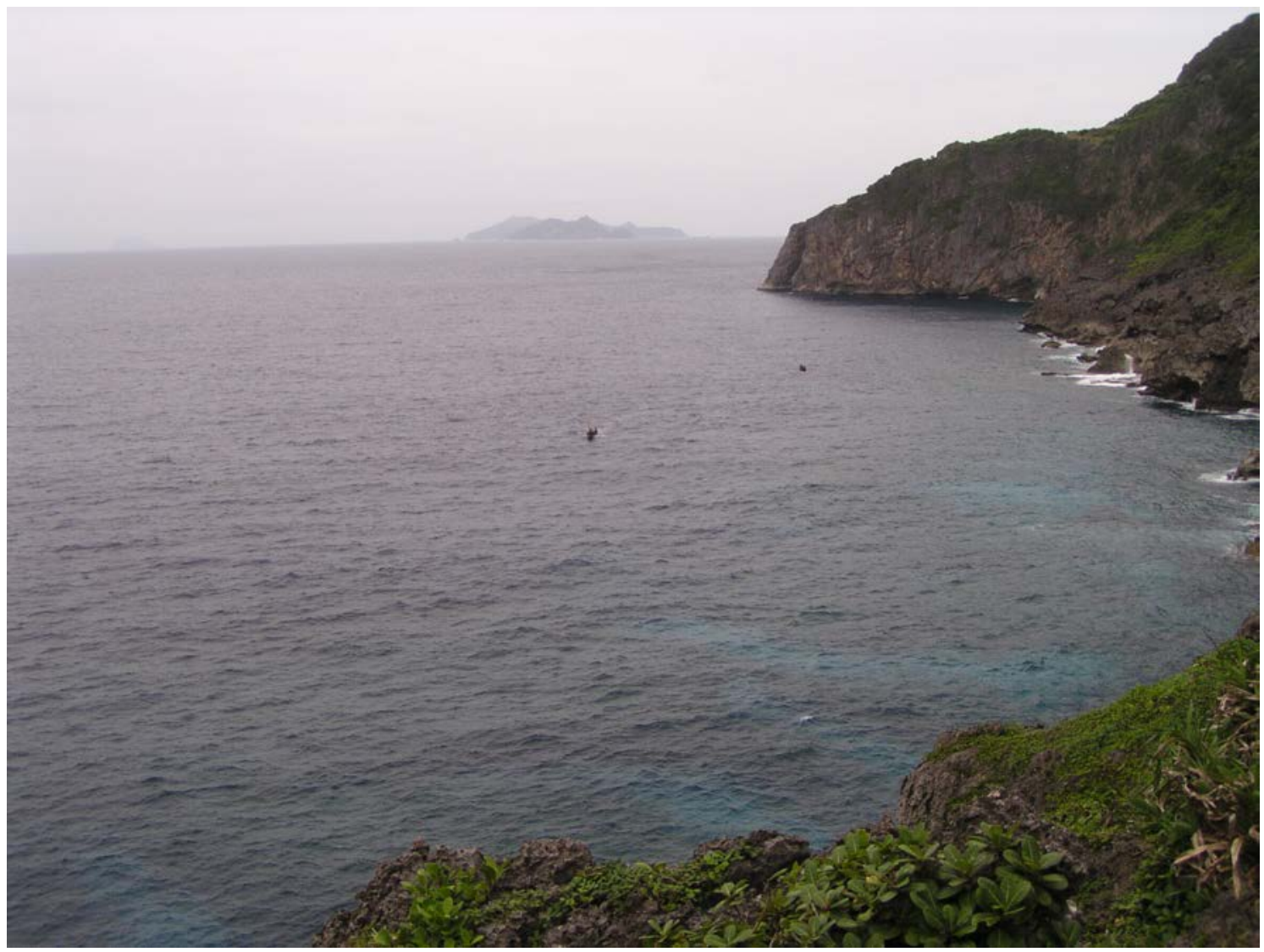

Figure 2.9. Looking north from below Reranum shelter towards Siayan Island, with Ditarem (Mabudis) Island behind it.

Source: Peter Bellwood.

The shelter itself is very small, enclosing about 5 by 6 meters, and lies perhaps $50 \mathrm{~m}$ above the sea, which is accessible by a steep climb down over razor-sharp karst, past the freshwater spring. Reranum was reported by Gershom P. Gato, Captain of Barangay Santa Rosa, Itbayat, to the research team in April 2006. That same month, three $1 \mathrm{x} 1$ square meters (Pits A, B and C) were excavated in the shelter, as indicated in Fig. 2.10. Unfortunately, the deposit in Reranum is only a maximum of $50 \mathrm{~cm}$ deep (Fig. 2.11) and shows many signs of disturbance, especially in square $\mathrm{B}$, where a large ash-filled pit was dug to bedrock quite late in the occupational history of the site and later sealed by fallen limestone rubble. The western end of the rockshelter has been badly disturbed by the removal of most of the deposit, perhaps by treasure hunter activity. The soil from this end had been thrown out of the cave, together with many earthenware sherds that had been collected by Mr Gato before our arrival and put in a pile inside the shelter. Many of these sherds were quite large, indicating that preservation in this part of the shelter was originally very good.

The distribution of cultural material by depth within the excavated Reranum squares is shown in Table 2.2. The single archaeological layer (layer 3 in Fig. 2.10) comprised homogenous dark soil, presumably derived from material slowly falling from upslope and behind into the shelter, entering around the sides. Sherd densities by soil volume were similar from surface to bedrock, and the latter was presumably exposed in the shelter floor when humans first utilised the site. The chronology of Reranum is discussed further in chapter 5, but the four C14 dates from it can best be described as chaotic, totally unrelated to the stratigraphy. There are probably two reasons for this, the first being simple disturbance, the second being the presence of a much younger archaeological site on the land surface immediately above the cave. Rim sherds from this 
ground surface are uniformly of the short everted types typical of the late, or Garayao Phase, of Itbayat prehistory (chapter 6), and sherds must have fallen down into the shelter deposits from above. Two of the C14 dates were on food residues on the inside surfaces of potsherds, and since such sherds inevitably came from the basal undecorated and unrimmed portions of pots it is impossible to guess their typological age simply by looking at them. It seems likely at Reranum that these food residues, unlike the situation in the more protected Torongan Cave, have only survived on chronologically recent sherds.

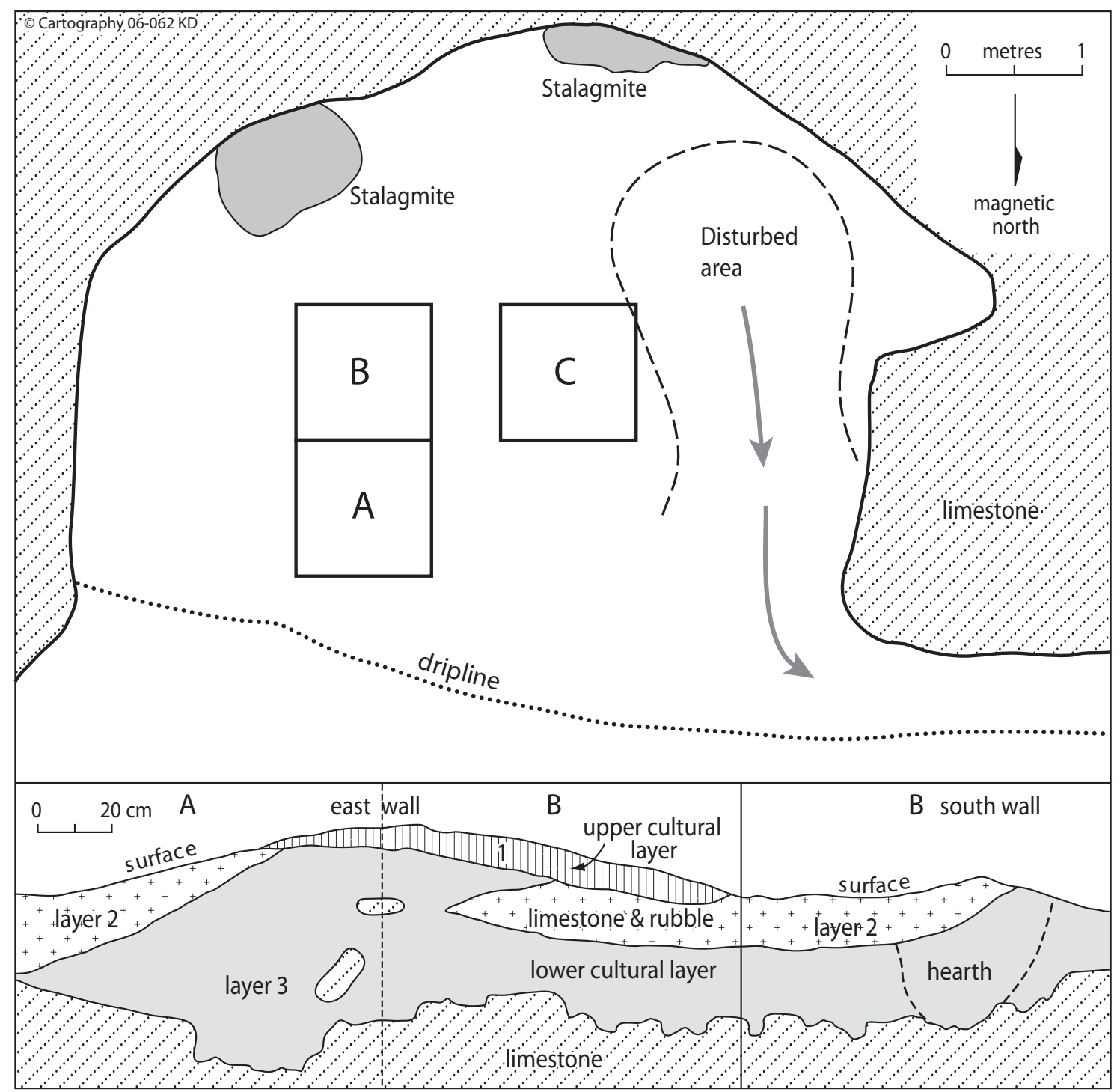

Figure 2.10. Plan and section of Reranum shelter.

Source: Map preparation by ANU College of Asia and the Pacific, CartoGIS. 


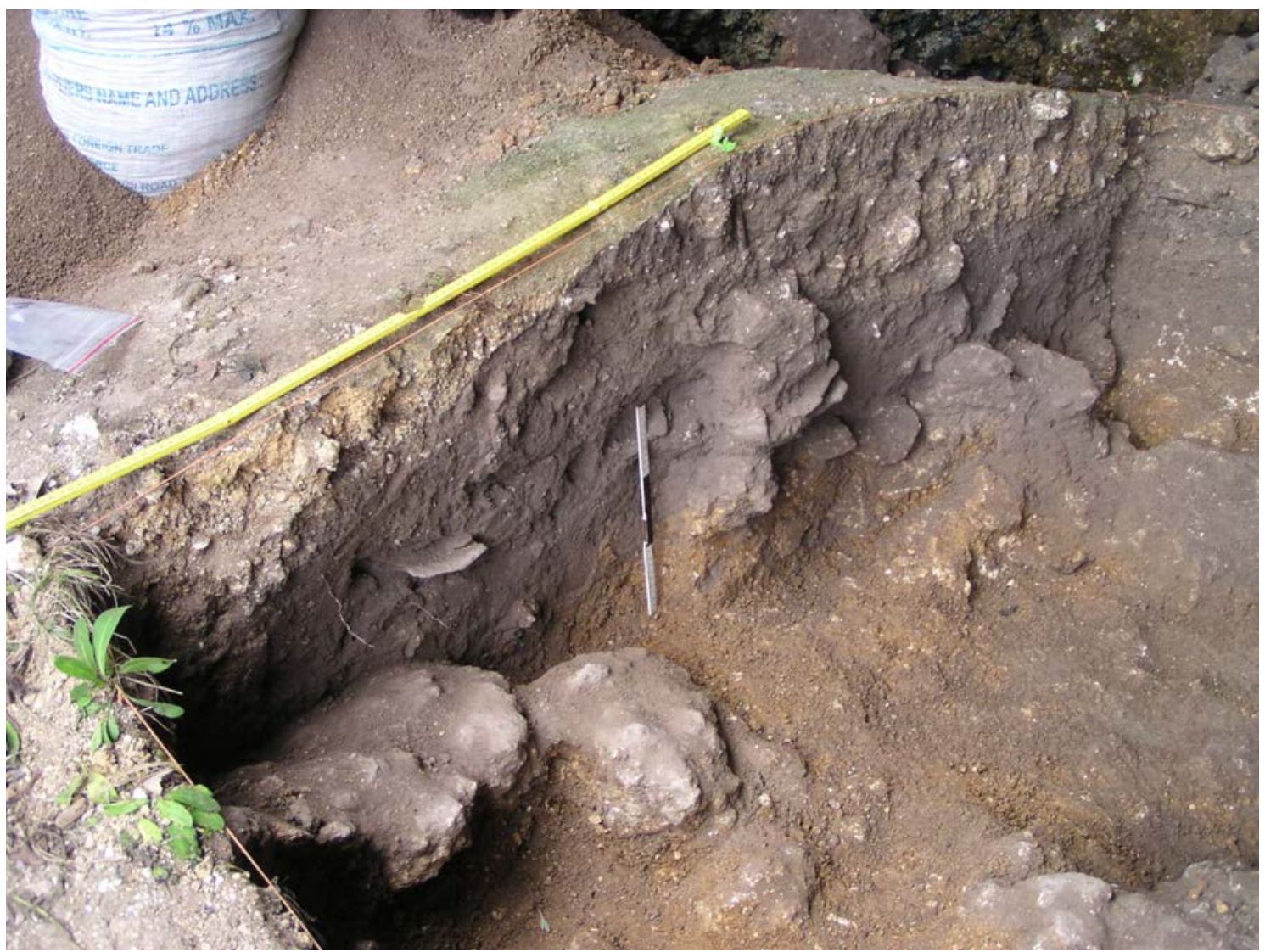

Figure 2.11. The excavated eastern section of squares $A$ and $B$, Reranum shelter.

Source: Peter Bellwood.

Table 2.2. The distribution of sherds by number and weight per $5 \mathrm{~cm}$ spit in Reranum, squares A to C. Because the floor of the shelter is very uneven, sherd counts drop off below $25 \mathrm{~cm}$ because smaller surface areas are represented. Given this, sherd densities by soil volume seem fairly even from surface to bedrock. Presumably the shelter had a bare and uneven rock floor when humans first occupied it.

\begin{tabular}{|l|l|l|l|l|l|l|}
\hline Reranum A-C & Plain body sherds (n0.) & Plain rim sherds & Fine cord-marked & Circle-stamped & $\begin{array}{l}\text { Total sherd weight } \\
\text { (gm) }\end{array}$ & $\begin{array}{l}\mathbf{C}^{14} \text { dates } \\
\text { (see Table 5.1) }\end{array}$ \\
\hline $0-5 \mathrm{~cm}$ & 490 & 9 & 2 & 0 & 4480 & \\
\hline $5-10 \mathrm{~cm}$ & 464 & 5 & 5 & 0 & 1920 & $768 \pm 34 \mathrm{BP}$ \\
\hline $10-15 \mathrm{~cm}$ & 252 & 6 & 2 & 0 & 1840 & \\
\hline $15-20 \mathrm{~cm}$ & 383 & 12 & 2 & 1 & 3540 & $479 \pm 30 \mathrm{BP}$ \\
\hline $20-25 \mathrm{~cm}$ & 589 & 21 & 7 & 0 & 4900 & \\
\hline $25-30 \mathrm{~cm}$ & 132 & 6 & 0 & 0 & 1560 & $3253 \pm 47 \mathrm{BP}$ \\
\hline $30-35 \mathrm{~cm}$ & 205 & 2 & 0 & 0 & 1790 & $1798 \pm 37 \mathrm{BP}$ \\
\hline $35-40 \mathrm{~cm}$ & 93 & 0 & 1 & 0 & 1000 & \\
\hline $40-45 \mathrm{~cm}$ & 15 & 0 & 0 & 0 & 40 & \\
\hline Total & 2623 & 61 & 19 & 1 & 21070 & \\
\hline
\end{tabular}

It can be seen from Table 2.2 that sherds of fine-corded marked pottery were found throughout the deposit in small numbers. Only one circle-stamped sherd was found. One significant observation about Reranum from the viewpoint of chronology is that the cord-marked sherds are all very small, suggestive perhaps of redeposition or disturbance from now-lost older layers. Cord 
marking had disappeared completely from southeastern Taiwan by 2000-1500 BC (Hung 2008), and its absence in Torongan Cave and in all archaeological sites in the northern Philippines, apart from Reranum, is hardly likely to be coincidental. It suggests a considerable age for the assemblage. Indeed, the rim forms of the sherds collected from Reranum by $\mathrm{Mr}$ Gato, to be discussed in chapter 6 , also belong from a Taiwan perspective to this early period.

\section{Anaro}

The ijang-like hilltop site of Anaro is placed centrally within northern Itbayat, $3.5 \mathrm{~km}$ south of the highest hilltop on the island, Mt Santa Rosa (or Karovooban), which rises to $277 \mathrm{~m}$ above sea level. It lies about $500 \mathrm{~m}$ inland from the southeastern edge of Mayan township, from which it is separated by a valley that is normally dry. The site covers the flat limestone top and upper terrace of a long narrow promontory of raised coral that runs northwest to southeast for about $150 \mathrm{~m}$, at about $100 \mathrm{~m}$ above sea level. At its southeastern end, Anaro is joined to another area of raised coral across a saddle, but is otherwise flanked by steep slopes strewn with fallen artefacts. The top of the promontory is a maximum of $40 \mathrm{~m}$ wide and the terrace that lies just below is about 3-5 metres wide (Figs 2.12, 2.13).

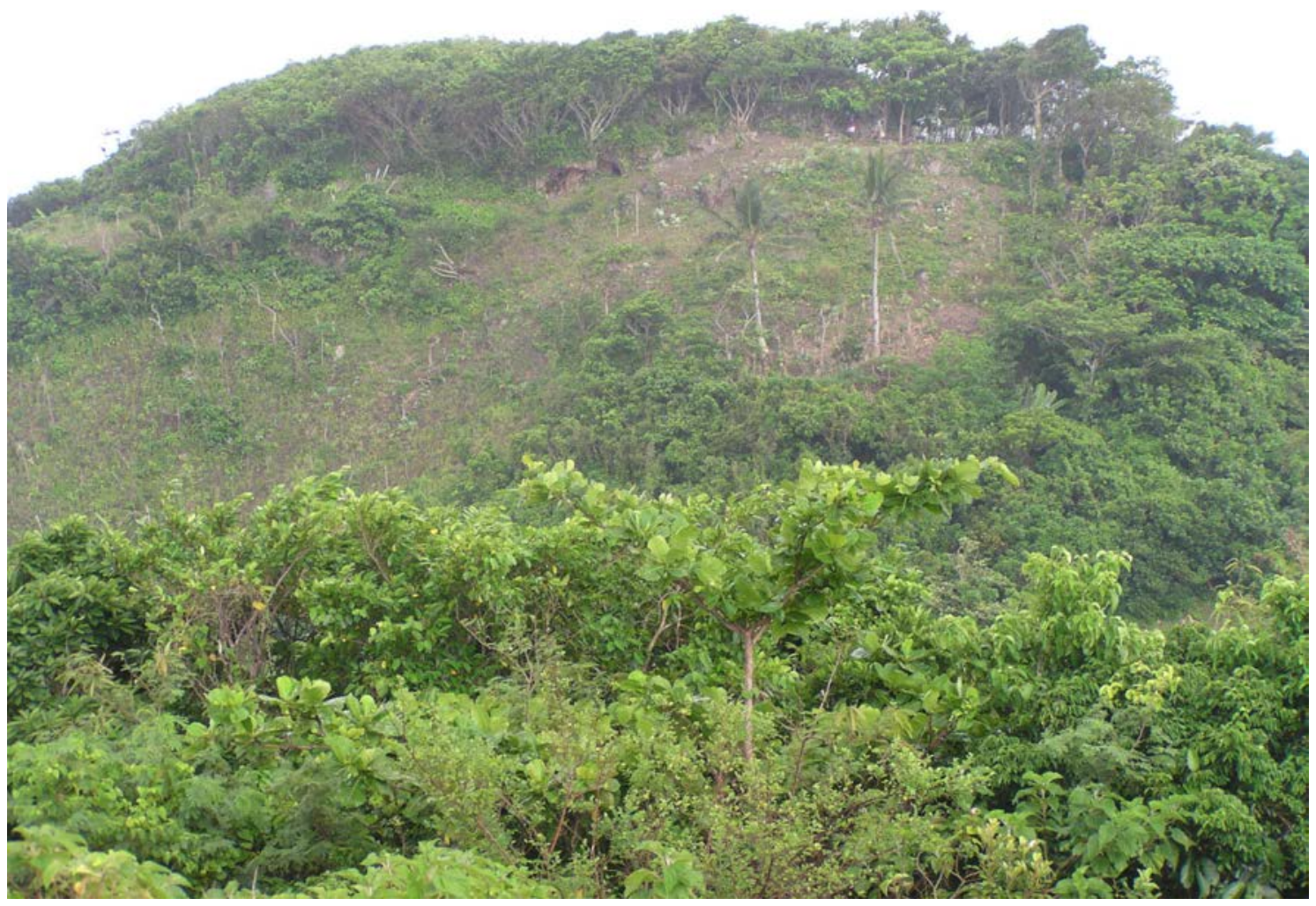

Figure 2.12. Anaro from the north. The cleared area in the centre of the photo contains the lower slope collection areas of Anaro 1 and 5. The low limestone cliff of the upper terrace is visible at the top of the clearing, just below the summit, with two small rockshelters (Anaro 1). The left hand end (east) is towards Anaro 2, behind the forest. Anaro 3 is over the back of the hill from the cleared area.

Source: Peter Bellwood. 


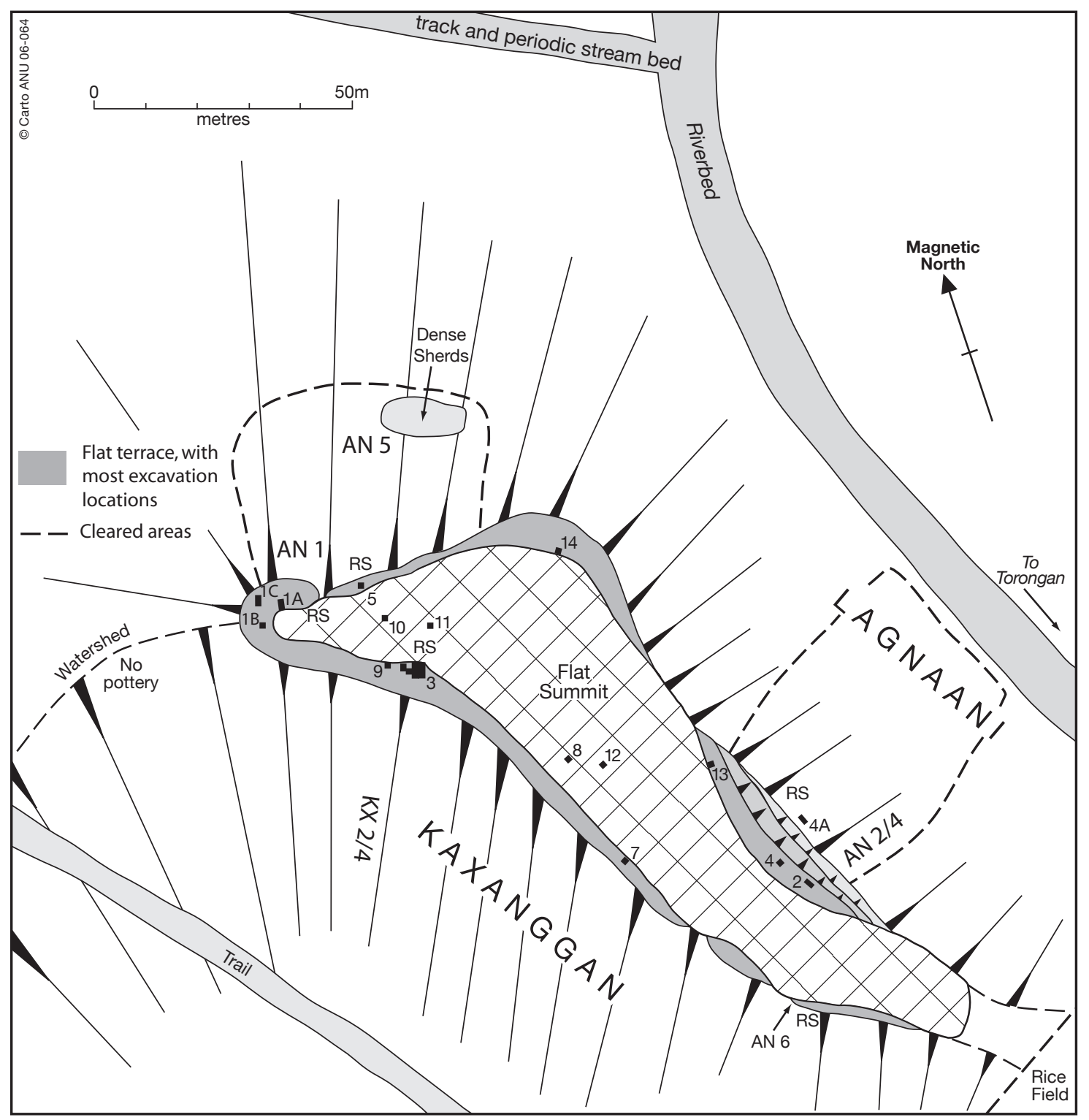

Figure 2.13. Plan of Anaro, with numbered excavation areas. The flat summit of the site is partly bare limestone and partly very thin soil with deeper pockets. No coherent archaeological stratigraphy remains here.

Source: Map preparation by ANU College of Asia and the Pacific, CartoGIS.

Anaro was originally a flat topped and steep sided coral reef, with its surface at sea level. Uplift took place, probably during the Pleistocene, in at least three episodes, indicated by the profile of the hill (Fig. 2.14). The first uplift was only about 2-3 metres, allowing the 3 to $5 \mathrm{~m}$ wide upper terrace that runs around most of the summit to be wave-cut, together with the rockshelters at Anaro 1 and 3. Two more uplift phases followed, cutting the two eastern cliffs below Anaro 2 and 4 that are shown in Fig. 2.13. There is also a lower level rockshelter at Anaro 6 on the western side of the hill, but this could perhaps be phreatic in origin. 


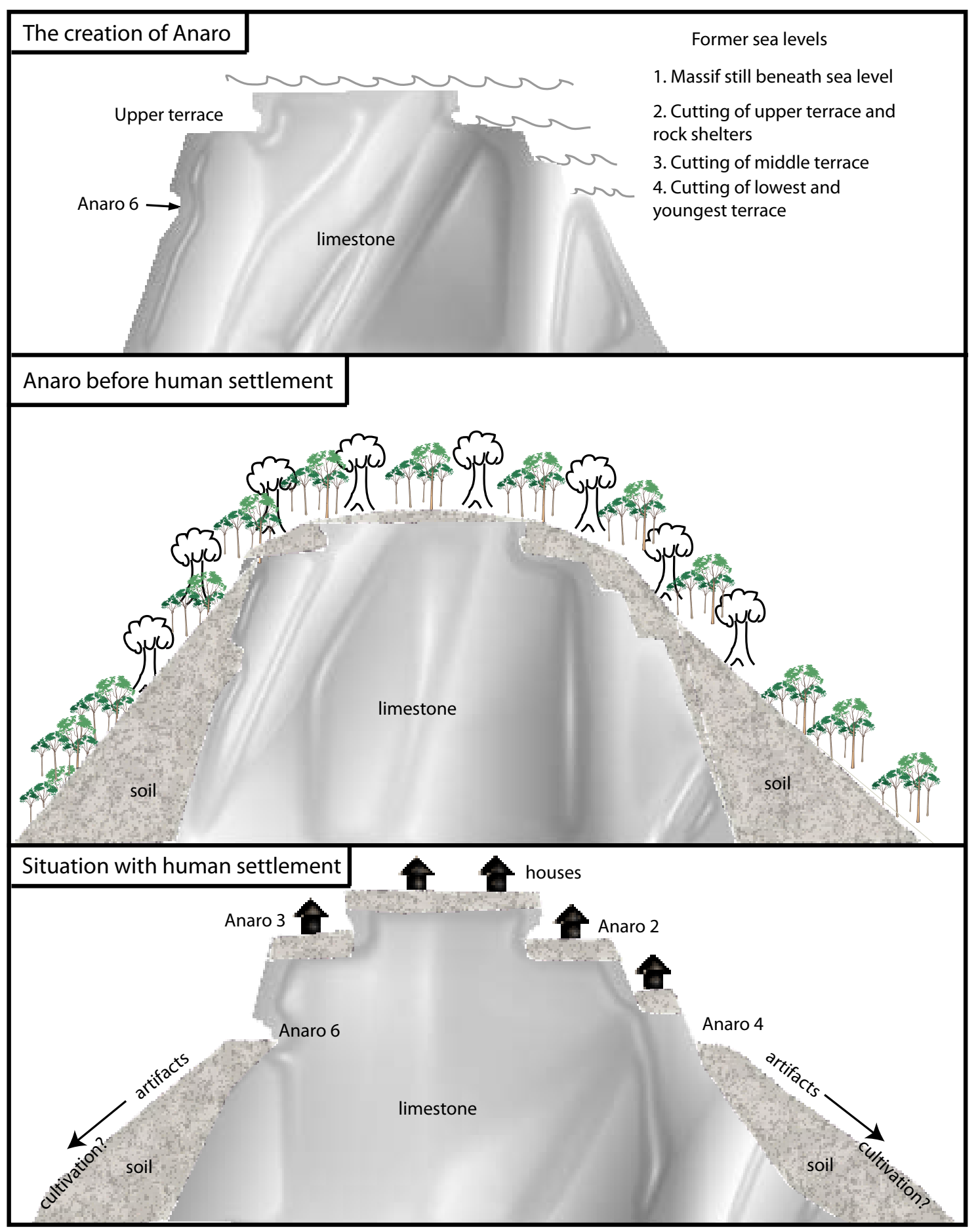

Figure 2.14. Anaro geological and occupational history. Three geological phases of wave-cut erosion are visible, not including the levelling of the flat top of the hill, presumably when it was an active reef surface.

Source: Tony Peñalosa and Peter Bellwood.

Prior to the first human arrival on Itbayat about 4000 years ago, the upper terrace would presumably have been mantled by soil ( $\mathrm{pH} 8.0$, alkaline) sloping down from the hill top above. Human activities have made the surface of this terrace virtually flat, especially at the northern end and down the western side, through digging stick cultivation, purposeful levelling for house 
floors, and so forth. During our excavations, some sections of the upper terrace were cleared for planting, as were the very steep slopes below. In recent times the flat limestone top of the site has held too little soil to support agriculture (pers. comm. from land owner Rodobaldo Ponce), being mostly now bare rock, but trees have been cut from this area in the recent past as firewood for burning lime.

Artefacts occur down to the flat bedrock base of the upper terrace in all excavated squares, especially in Anaro 2 and 3, although this need not imply that the base was bare rock when first settlement occurred. There was probably already a layer of soil. Digging stick activity would continuously have rotated artefacts through a vertical height of around $30 \mathrm{~cm}$ as the upper terrace deposit deepened, except during actual house-dwelling episodes. For instance, three matching rim sherds of one Anaro circle-stamped type 1 vessel (described in chapter 6) were found in square 3 at $70-80 \mathrm{~cm}$, at $90-100 \mathrm{~cm}$, and in neighbouring square $3 \mathrm{G}$ at $80-90 \mathrm{~cm}$, suggesting considerable disturbance by cultivation and tree roots.

Anaro was subjected to excavation by a series of one metre squares in 2004, 2005 and 2006 (Fig. 2.13), eventually totalling 28 square metres in 16 different locations. Nine of these one metre squares were clustered at the location termed Anaro 3, where a rockshelter $1.2 \mathrm{~m}$ deep and 2.5 $\mathrm{m}$ long has been etched into the back wall of the upper terrace. Prior to excavation this shelter was filled with $75-100 \mathrm{~cm}$ of archaeological deposit, with only about $50 \mathrm{~cm}$ of vertical space remaining below its roof. The original height of the shelter when empty was thus about $1.5 \mathrm{~m}$ from bedrock to ceiling (Figs 2.15, 2.16). It is unlikely that it was ever formally inhabited, being too small, but it is important because it has retained a deposit approximately one metre deep, relatively undisturbed by tree roots or by the cultivation activities that have taken place outside on the terrace itself. We return to this situation later when the chronology of the site is discussed.

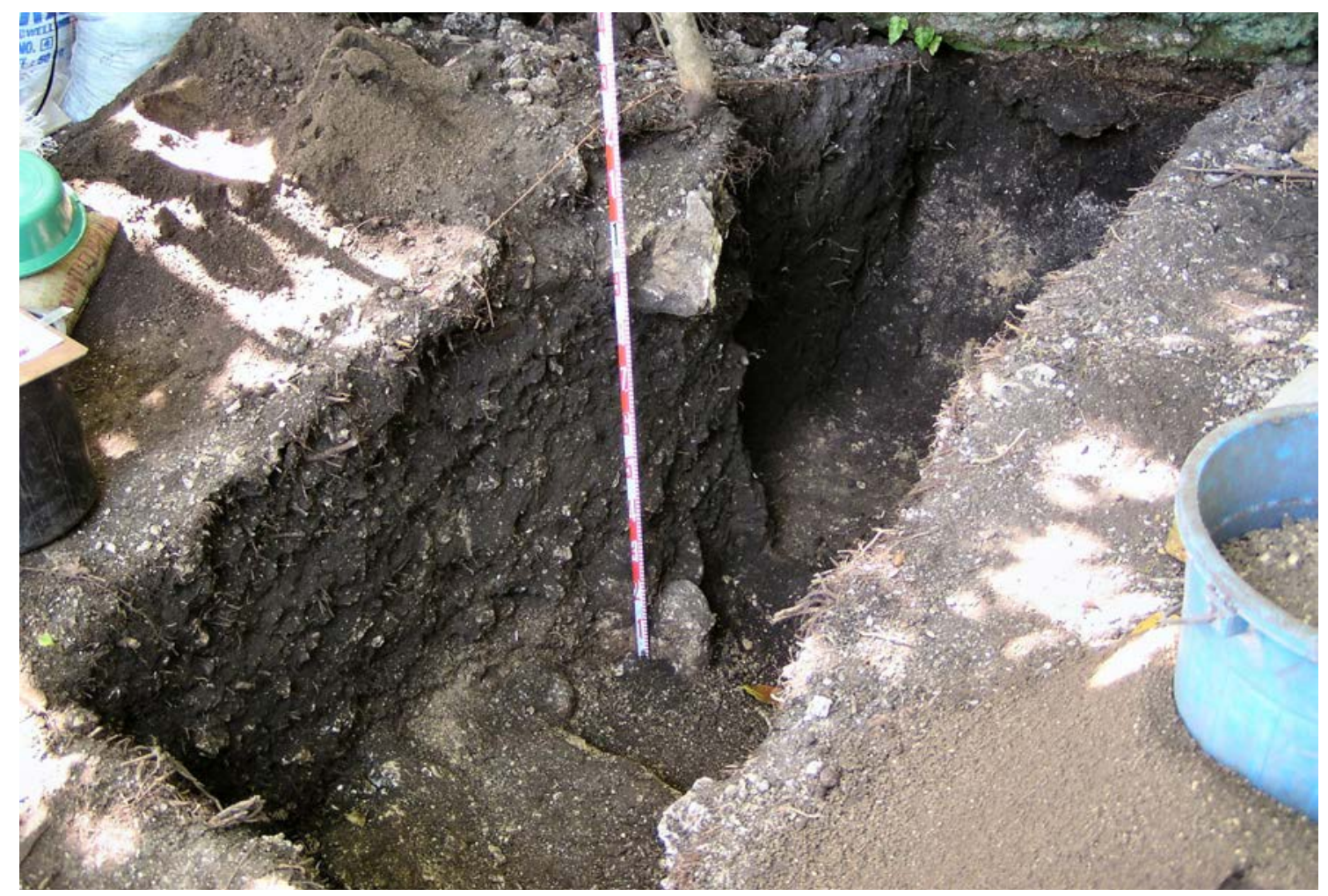

Figure 2.15. Anaro 3A (at rear, against exposed rockshelter wall) to 3C, excavated in 2005.

Source: Peter Bellwood. 


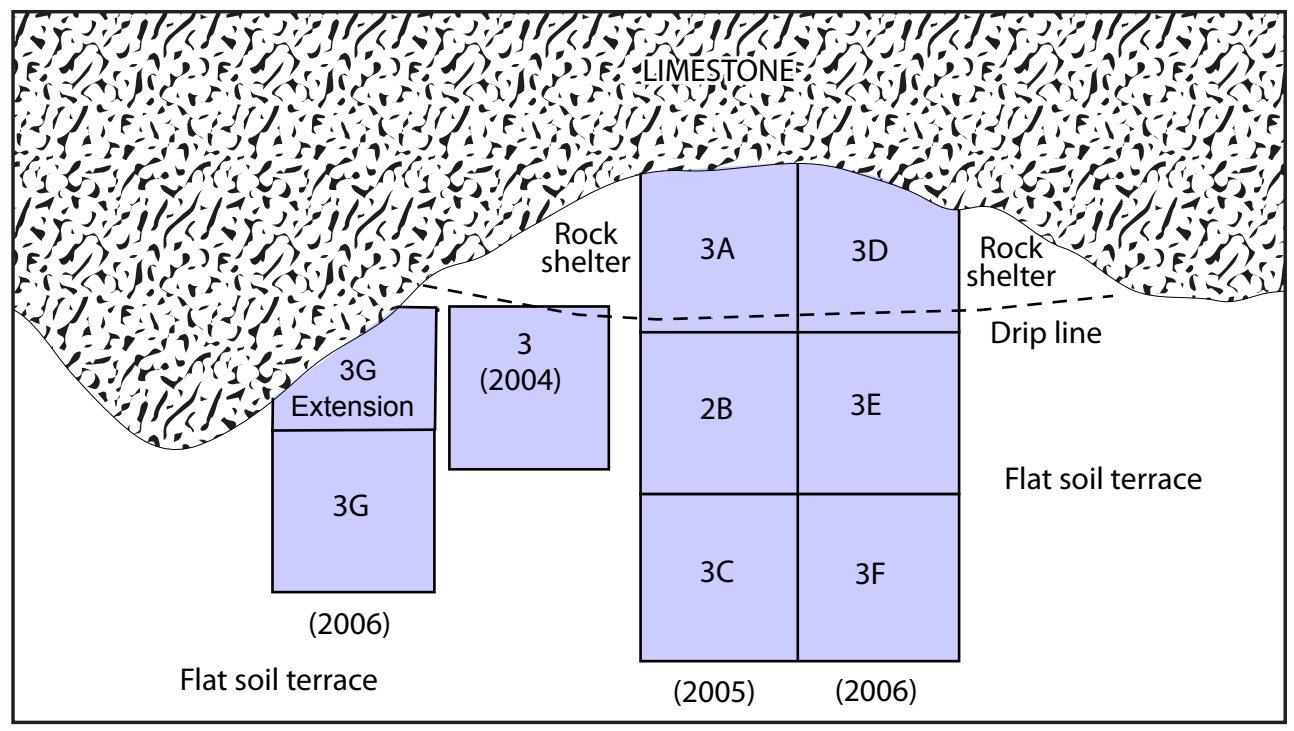

Figure 2.16. Plan of excavated squares at Anaro 3. Squares 3A and 3D lie within a small rockshelter.

Source: Peter Bellwood.

Apart from Anaro 3 and 6, the latter also a rockshelter, the other Anaro excavations mostly had very shallow deposits over bedrock in areas which had been subjected to cultivation in the past. In fact, in no trench was there any significant stratigraphic differentiation of separate soil layers. The soil deposits in all squares, outside rock shelters, were identical from surface to bedrock, consisting of a garden soil with tree roots, artefacts, shells, animal bones and so forth, in fairly similar concentrations throughout. Lower layers were usually more compact than upper, but this is to be expected due to the passage of time.

Most excavation took place in $5 \mathrm{~cm}$ spits, but for analytical purposes the data are discussed below by $10 \mathrm{~cm}$ spits. Nowhere was it evident that $5 \mathrm{~cm}$ spits were essential for interpretative purposes. All deposits were passed through $5 \mathrm{~mm}$ sieves, the soil being too hard and lumpy to pass through anything smaller. The absence of water near the site ruled out wet sieving. No charcoal concentrations were found, no hearths, and all C14 dates have come from food residues in sherds.

\section{The excavated areas at Anaro}

In this section the excavated squares are each described briefly with respect to depth and cultural content. We begin with Anaro 1, which comprised three trenches excavated at the northern end of the terrace in 2004 . One 2 by $1 \mathrm{~m}$ trench (1A) was dug in front of a small shelter in the rock face, and another of the same size (1C) out on the terrace. A 1 by $1 \mathrm{~m}$ square, $1 \mathrm{~B}$, was dug nearby to the south. The deposits in $1 \mathrm{~A}$ and $1 \mathrm{C}$ were only about $30 \mathrm{~cm}$ deep, had been cultivated to bedrock (this area is still planted today), and produced only very recent pottery. Evidently, any older deposits here will have cascaded downhill over the edge of the terrace in the past. Square $1 \mathrm{~B}$ went down to $60 \mathrm{~cm}$, but was mostly rock filled. It produced a sequence similar to Anaro 3 (below).

Anaro 2, a 3 by $1 \mathrm{~m}$ trench excavated in 2004, was located at the opposite end of the site from Anaro 1. Most of the deposit here lay between the surface and $30 \mathrm{~cm}$ depth, but pockets of material in the uneven limestone contained artefacts to $50 \mathrm{~cm}$, including a bark cloth beater at the base of a hole in the bedrock (Fig. 8.7 D). All of the deposit seems to have been very thoroughly cultivated in the past, being garden soil throughout. A food residue AMS date of c.AD 100 (Wk 14643) came from a depth of 15-20 cm (chapter 5). 
Anaro 3 is a complex area of excavation, within and in front of the rockshelter described above, with a total of 9 excavated 1 by 1 metre squares (Fig. 2.16). The single square termed Anaro 3 was dug in 2004 and is distinguished as Anaro 3 (2004) below, to avoid confusion with the use of the term Anaro 3 to refer to the whole area. Anaro squares 3A to $3 \mathrm{C}$ were dug in 2005, and 3D to $3 \mathrm{G}$ in 2006. Anaro 9 nearby was mostly loose rock. Squares 3A and 3D were actually within the rockshelter, the others in front. Depths of these deposits varied slightly; Anaro 3 (2004) and $3 \mathrm{~A}$ reached bedrock at $110 \mathrm{~cm}, 3 \mathrm{~B}$ and $3 \mathrm{C}$ at $100 \mathrm{~cm}$, but $3 \mathrm{D}$ and $3 \mathrm{E}$ reached only $80 \mathrm{~cm}, 3 \mathrm{~F}$ and $3 \mathrm{G} 90 \mathrm{~cm}$. All squares had homogeneous garden soil profiles, with lots of tree roots outside the shelter.

The remaining squares, Anaro 4 and $4 \mathrm{~A}$, through to Anaro 14, were mostly one metre squares dug in various parts of the site. Apart from Anaro 4A, which was dug between large rocks at the top of the soil scree slope and thus "bottomless" (we dug to $100 \mathrm{~cm}$ but then gave up since the area was becoming too constricted), most of these squares were very shallow. Anaro 5 reached a maximum of $40 \mathrm{~cm}$, Anaro 11 only $20 \mathrm{~cm}$. Anaro 14 reached $50 \mathrm{~cm}$. In all of these squares the bedrock is always uneven, so the deepest deposits are normally in little more than a small hole in the rock. Rock-free deposits rarely go below $20 \mathrm{~cm}$ from the surface, and this is true also of Anaro 2.

Anaro 6 was the only significant rockshelter excavation, apart from that at Anaro 3. However, Anaro 6 lies well below the main terrace, in the side of the hill, and gives the impression of being a phreatic "hole in the wall" rather than a wave-cut shelter. Excavation of a one metre square within the cave produced pottery down to $130 \mathrm{~cm}$, with culturally sterile soil below. We never reached bedrock, since the cave probably never had a flat floor and the soil deposits doubtless continue as the scree slope for tens of metres below. Strangely, the pottery from this excavation was very homogeneous and relatively recent, with strong Mitangeb parallels. Perhaps it washed into the shelter as a result of some disturbance above, possibly during clearance and cultivation, since there were few signs that this small and dark shelter was ever actually inhabited.

\section{Mitangeb, Siayan Island}

Since Mitangeb produced a short-lived but well defined assemblage of Anaro-style plain pottery dated to about AD 1-500, the site is described here with Anaro. Getting to the uninhabited island of Siayan can best be described as an adventure, involving a $15 \mathrm{~km}$ small open boat trip from the Paganaman Landing near Mayan township on Itbayat. Siayan has no reliable fresh water supply so all supplies must be carried in, and visitors have to camp. The island is entirely volcanic and quite rugged (Fig. 2.3), peaking at $164 \mathrm{~m}$ above sea level. The site of Mitangeb, shown to us in 2004 by the Captain of Barangay Santa Rosa, Gershom P. Gato, lies on a terrace above a protected beach on the southwestern side of the island (Fig. 2.17). A small test pit dug hurriedly during our one-day visit in 2004 produced sherds at 50 to $85 \mathrm{~cm}$ below ground level, with the greatest density at $70-75 \mathrm{~cm}$.

The general layout of the site is shown in Figs 2.17 and 2.18. The excavated area sits on a low terrace above a coral sand beach, inland from a shallow marine lagoon that is almost dry at low tide, with a reef beyond. Fig. 2.17 shows the site at high tide. Between the beach sand and the site is an area of very dense spiny pandanus, but all indications are that the site only exists above the break of slope shown on the plan, covering an area on the terrace about $25 \mathrm{~m}$ long by $15 \mathrm{~m}$ wide, according to auger holes that yielded potsherds. In 2006 we laid out three excavations, trench A at $2 \times 1$ metres, and squares $B$ and $C$ at $1 \times 1$ metre each. Each yielded identical stratigraphy, except that the main cultural layer 4 in $\mathrm{C}$ was more deeply buried, at about one metre as opposed to $60 \mathrm{~cm}$ in A and B. Although the surface of the site is level now, at the time of occupation the 
surface sloped downwards from A to C, perhaps reflecting the former presence of a gully. Trench A yielded the most interesting material, especially a layer of quite dense stones that might have belonged to a house floor or pavement of some kind, with dense sherdage in association (Fig. 2.19). This suggests the presence of a feature that could have been about $3.5 \mathrm{~m}$ long, given that the stone layer also appeared in the SW corner of square B.

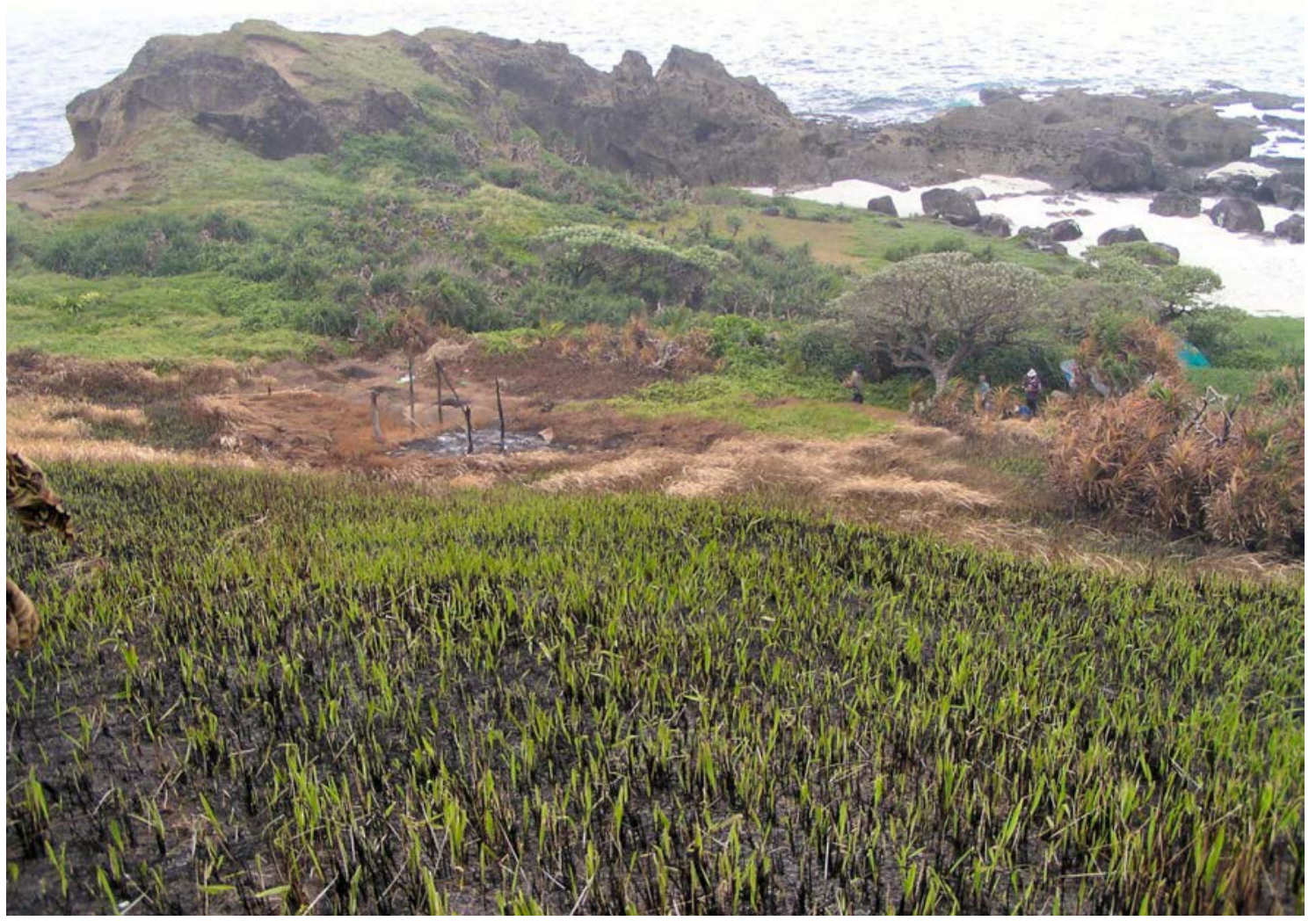

Figure 2.17. A view of Mitangeb from the southern slope of Domnayjang. The three excavation squares can be seen behind the burnt posts in the left middle ground.

Source: Peter Bellwood.

In each square there were 5 main layers, with $\mathrm{pH}$ values of 6 , neutral to acid. Hence the site yielded no animal bone, and little shell, mostly Turbinidae and Thais sp. and probably of industrial rather than food origin. Layer 1, at the surface, was simply a blown beach sand, quite deep on top of square $\mathrm{C}$, where it seems to have been filling the depression or gully, but virtually absent in squares A and B. Layer 2 is a culturally-sterile topsoil, indicating that the site has not been inhabited in recent centuries. Layer 3 consists of another yellowish beach sand, also culturallysterile. Layer 4, the main cultural layer, is a buried topsoil $20-30 \mathrm{~cm}$ thick that clearly formed the occupation layer for the site (Fig. 2.19). Layer 5 beneath is a culturally-sterile clay, except for a few sherds and the sinker/anvil shown in Fig. $8.10 \mathrm{D}$ pressed into its top. Coring through layer 5 revealed that it is about $35 \mathrm{~cm}$ deep and seals in another old topsoil (layer 6), in turn about $50 \mathrm{~cm}$ deep, over light brown subsoil. Rocks below this terminated augering. One suggestion from this sequence could be that layer 6 is the early human phase topsoil, buried by clay soil wash released by deforestation before the Mitangeb site was inhabited. The pinnacle of Domnayjang behind Mitangeb, visible in Fig. 2.3, would certainly have produced considerable hill wash material if its lower slopes were cleared of vegetation. However, deeper investigation is required to demonstrate this possibility. 


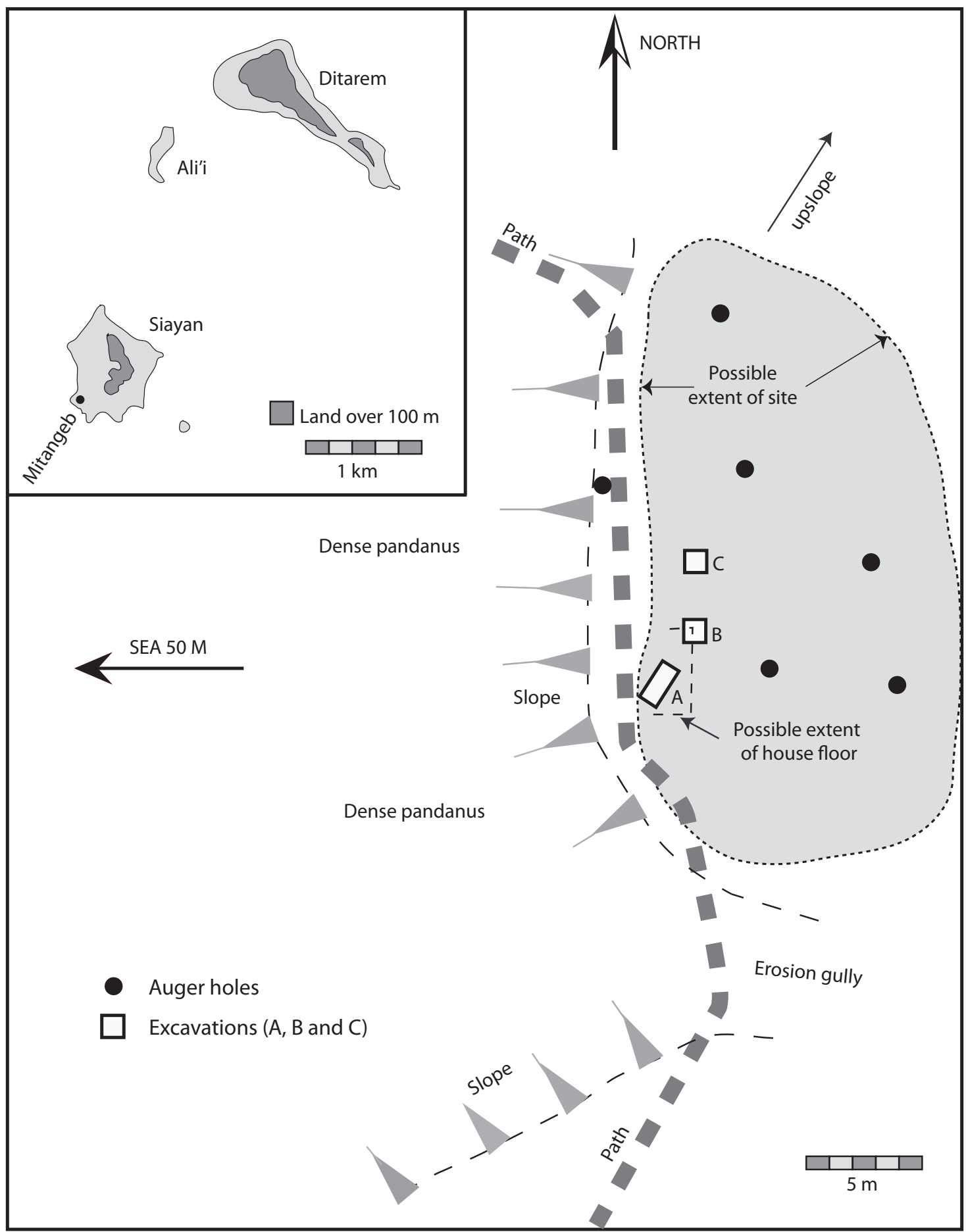

Figure 2.18. Plan of the Mitangeb site.

Source: Peter Bellwood. 


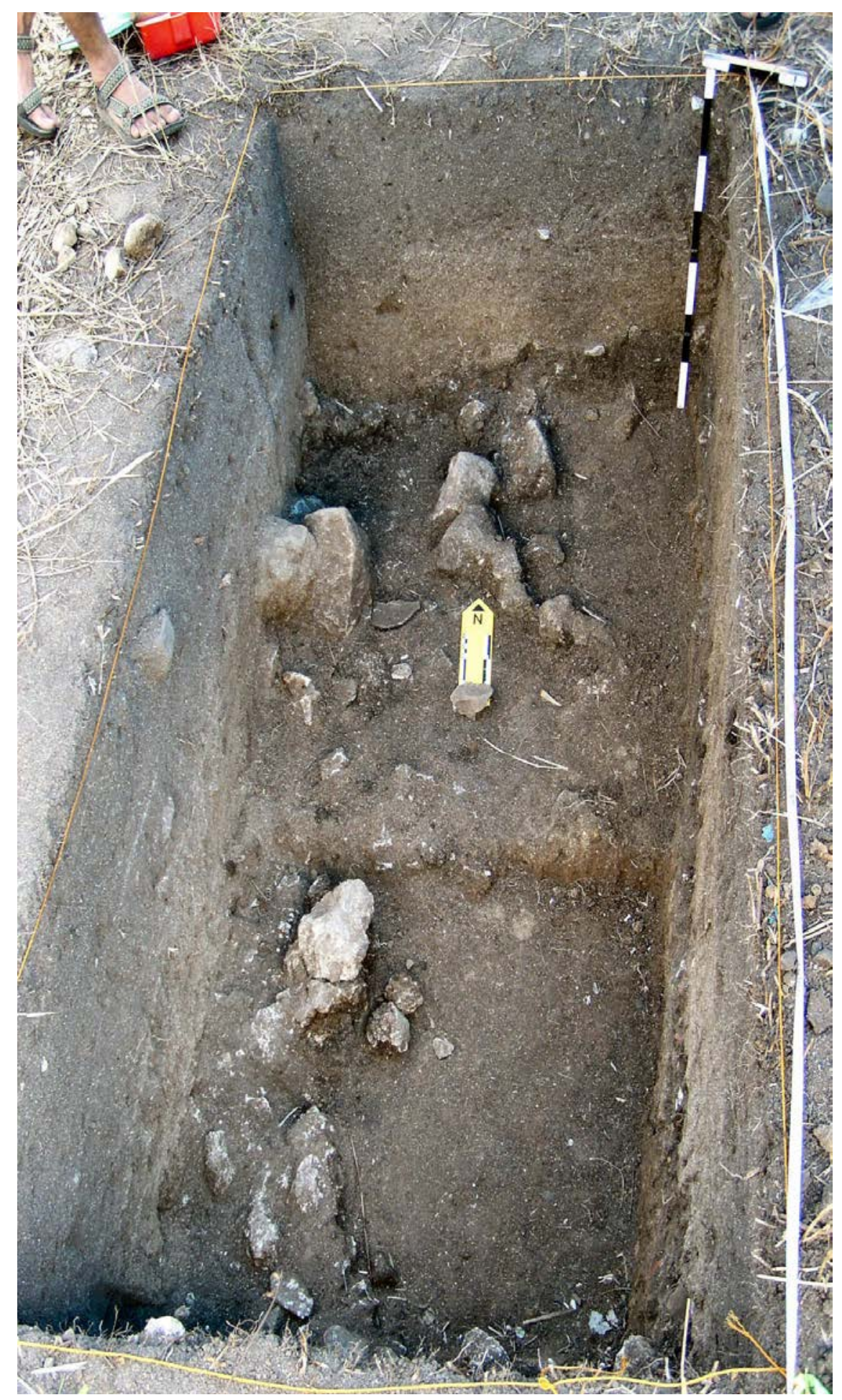

Figure 2.19. Mitangeb square A, looking towards the north. The stones and dark topsoil of cultural layer 4 are clearly visible. Source: Peter Bellwood. 